\title{
Nitrogen fluxes through the upper estuary of the Great Ouse, England: the role of the bottom sediments
}

\author{
D. B. Nedwell*, M. Trimmer \\ Department of Biology, University of Essex, Colchester CO4 3SQ, United Kingdom
}

\begin{abstract}
The fate of nitrogen $(N)$ in the bottom sediments of the upper Great Ouse estuary, England, was examined over the course of a year. The sediments were consistent sinks for $\mathrm{NO}_{3}{ }^{-}$from the overlying river water, and were weak sources of $\mathrm{NH}_{4}{ }^{\circ}$. Simultaneous measurements of oxygen uptake, nutrient exchange and sulphate reduction, when combined with the measured $C: N$ ratios of the sediment organic matter, permitted calculation of the amount of $\mathrm{N}$ released within the sediment by organic matter mineralisation. With the exception of a site with thixotropic sediment, at all other sites the amount of inorganic $N$ entering the sediment by transport from the overlying water and by internal ammonification of organic matter was not matched by measured exports of $\mathrm{N}$ from the sediments. We calculate that $>90 \%$ of the flux of $\mathrm{N}$ through the sediment was lost as gases, and that $50 \%$ of the $\mathrm{N}$ ammonified from organic matter must have been converted to gases by coupled nitrification-denitrification within the sediments. When compared to the total flux of $N$ through the entire estuary, any $N$ loss by denitrification in the sediments of the upper estuary was minor $(\sim 1 \%)$ because of the small surface area of sediment to freshwater flow.
\end{abstract}

KEY WORDS: Bottom sediments · Nutrient fluxes Organic mineralisation · Denitrification

\section{INTRODUCTION}

Estuaries are the interfaces between land and coastal seas, through which pass material leached from land into the rivers, together with anthropogenic material discharged directly into the estuaries. Over the past few decades there has been increasing concern. over the trophic status of estuaries and coastal seas, particularly with regard to the increased fluxes of nutrients such as nitrate and phosphate. Increasing fluxes of nitrogen $(N)$ have been of particular concern as primary production is usually limited by $\mathrm{N}$ availability (Boynton et al. 1982). Estuaries are highly productive, but the addition of hitherto limiting nutrients may stimulate biological productivity. The concern over eutrophication in the North Sea has been reviewed in the recent Quality Status Report (North Sea Task Force

-E-mail: nedwd@essex.ac.uk
1993), and the previous Second International Conference on the Protection of the North Sea (1987) decided to reduce inputs of $\mathrm{N}$ and phosphorus (P) to areas where inputs were likely to cause pollution, by $50 \%$ by 1995.

It has been estimated that $670 \mathrm{kt}$ of $\mathrm{NO}_{3}{ }^{-}$and $1000 \mathrm{kt}$ of total $N$ entered the North Sea in 1990 (North Sea Task Force 1993), the majority of which was riverine discharge. However, it is also known that there can be significant removal of nutrients as they pass through estuaries (Nedwell 1975, Seitzinger et al. 1980, Billen et al. 1985, Jørgensen \& Sørensen 1988, Zwolsman 1994), although the proportionate attenuation of nutrient fluxes is poorly defined and the true net output from estuaries to the sea remains largely unknown. Balls (1994) has suggested that the attenuation of the estuarine nitrogen flux is related to the flushing time of the estuary.

The present work was undertaken to examine the flux of nutrients through a number of estuaries on the 
East Coast of the United Kingdom, as part of the JoNuS (Joint Nutrient Study) programme. One of the major estuaries is that of the Great Ouse (Dyer \& Grist 1987. Gould et al. 1987) which enters the North Sea through the Wash (Fig. 1). The catchment area of the Great Ouse $\left(8380 \mathrm{~km}^{2}\right)$ is largely rural and has a population of $1.4 \times 10^{5}$ (Gould et al. 1987). The main discharge of Sewage Treatment Works (STW) effluent occurs on the ebb tide $2.5 \mathrm{~km}$ seaward of King's Lynn. Annual average freshwater flow through the Great Ouse was 32 and $50 \mathrm{~m}^{3} \mathrm{~s}^{-1}$ in 1992 and 1993, respectively, contributing $50 \%$ of the freshwater input to the Wash. The annual Total Oxidized Nitrogen (TON; nitrate + nitrite) fluxes during these years were 0.6 and 1 Gmol, respectively, contributing about 6 to $10 \%$ of the TON load to the North Sea (National Rivers Authority, UK, unpubl. data).

\section{METHODS}

Sample sites. The study area comprised 4 sites (Fig. 1) along a $25 \mathrm{~km}$ reach of the Great Ouse estuary between, landward, Denver Sluice and, seaward, King's Lynn. This part of the estuary is narrow (<70 m width), shallow (1 to $7 \mathrm{~m}$ at low water) and predominantly canalised (Fichez et al. 1992)

Sediment characteristics. Sediment particle size: Small perspex cores $(20 \mathrm{~cm}$ long $\times 2.4 \mathrm{~cm}$ inner diameter) were used to collect duplicate sediment samples over a 0 to $15 \mathrm{~cm}$ depth from Denver Sluice (Site 1), Stowbridge (Site 2), Magdalen bridge (Site 3), and at King's Lynn (Site 4). In the laboratory each core was extruded and sectioned into 3 slices $(0-5,5-10$ and $10-15 \mathrm{~cm}$ ) and dried at $105^{\circ} \mathrm{C}$ to constant weight. Samples were then disaggregated with a mortar and pestle

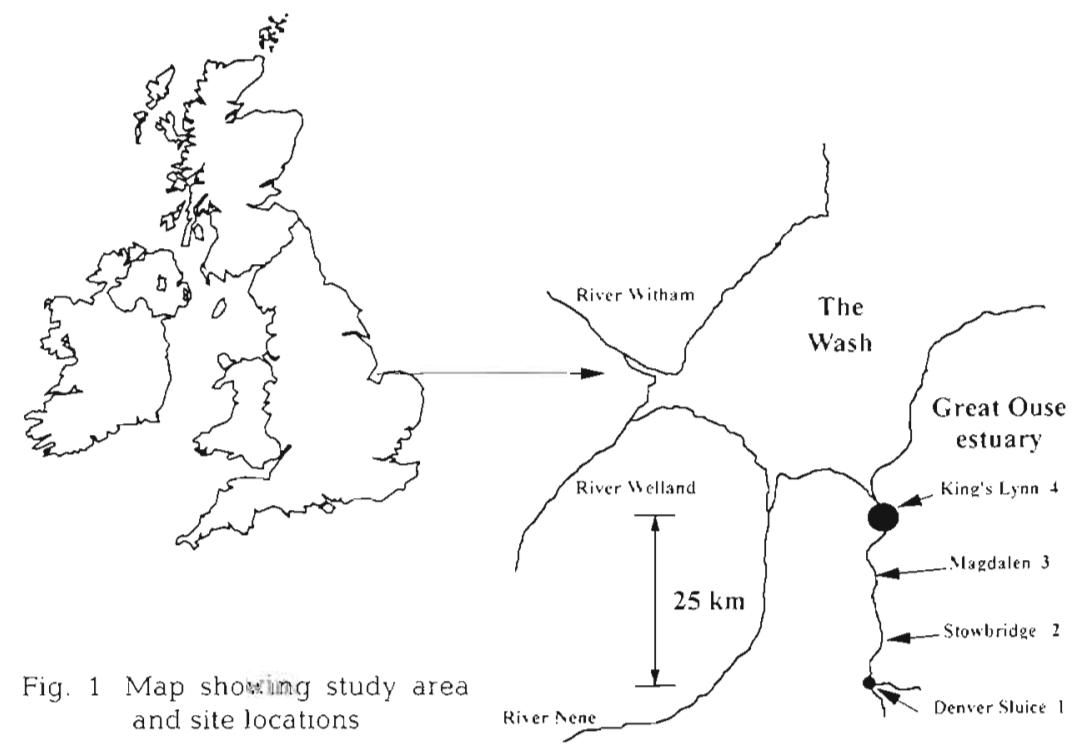

and shaken through a series of pre-weighed steel mesh sieves (mesh sizes 500, 250, 125 and $65 \mu \mathrm{m}$ ). Each sieve was then re-weighed and the dry weight of each size fraction expressed as a percentage $(w / w)$ of the total weight

Sediment porosity: This was determined from the dry weights and wet weights of known volumes of sediment collected by coring from each of the 4 sites on each sampling occasion.

Sedimentary organic matter, carbon and nitrogen contents: On each sampling occasion duplicate sub-samples $(5 \mathrm{ml})$ were taken over the 0 to $15 \mathrm{~cm}$ horizon from sediment cores and stored at $-20^{\circ} \mathrm{C}$ until analysed. Samples were then thawed and wet and dry weights determined. Each sample was homogenised with $5 \mathrm{ml}$ of hydrochloric acid $(1 \mathrm{M})$ to remove carbonate, and after re-drying, sub-samples $(20 \mathrm{mg})$ were analysed for their organic $\mathrm{C}$ and $\mathrm{N}$ contents with a CHN analyser (model 2400, Perkin-Elmer Ltd, Norwalk, CT, USA) calibrated with standard acetanilide $(71.09 \% \mathrm{C}, 10.36 \% \mathrm{~N})$.

Sediment temperature: Temperatures were measured with a mercury thermometer inserted into the surface sediment layer

Salinity: The salinity of the overlying estuarine water and of sediment pore water was determined with a refractive salinometer (model 10419, Reichert-Jung, Buffalo, NY, USA)

Dissolved $\mathrm{O}_{2}$ : Samples of water were collected and analysed for dissolved $\mathrm{O}_{2}$ by Winkler oxygen determination (Mackereth et al, 1978).

Vertical concentration profiles of dissolved $\mathrm{O}_{2}$ : These were determined in both in situ sediments exposed at low tide and in cores returned to the laboratory, using a Clarke-type $\mathrm{O}_{2}$ microelectrode in a steel hypodermic needle (van Gemerden, University of Groningen, The Netherlands). The microelectrode was calibrated in aerated river water $(100 \%)$ and in water with added sodium dithionite $(0 \%)$. It was then introduced into the overlying water and down into the sediment using a micro-manipulator (capable of $100 \mu \mathrm{m}$ steps) clamped to a retort stand, taking readings of dissolved $\mathrm{O}_{2}$ at $0.5 \mathrm{~mm}$ intervals

Rate measurements. Benthic oxygen uptake: Triplicate sediment cores $(-20$ $\mathrm{cm}$ deep) and overlying water (approx. 1 1) were collected from each site with perspex core tubes $(65 \mathrm{~cm}$ long $\times 8 \mathrm{~cm}$ inner diameter), each sealed at the bottom with a silicon rubber bung The tubes were capped to reduce movement in the overlying water and to keep perturbation of the surface sediment to a minimum during their transport back to 
the laboratory $(<3 \mathrm{~h})$. In the laboratory, cores were uncapped, the overlying water column adjusted to $1 \mathrm{l}$, and the cores were immersed in aerated estuarine water taken from the same site, at in situ temperature, to re-equilibrate overnight.

The tubes were recapped and completely waterfilled to exclude air bubbles. The rates of benthic $\mathrm{O}_{2}$ uptake were measured as described by Nedwell et al. (1993b, 1994), with the difference that each core tube had an $\mathrm{O}_{2}$ electrode (model 1302, Strathkelvin Ltd, Glasgow, UK) coupled to a 6-channel $\mathrm{O}_{2}$ meter (Essex Electronics Centre, Colchester, UK) The multi-channel $\mathrm{O}_{2}$ meter was connected to a computer (V.I.P computers, Manchester, UK) with data analysis software (Notelog, Garrat Consultants, Colchester) which logged, displayed and analysed the data. The onscreen computer logging enabled the oxygen concentration in the water column to be continuously monitored and statistically analysed for linearity with respect to time. This allowed the period of each oxygen uptake trial to be altered, depending on how rapidly a steady linear relationship was achieved. It was also possible to see whether the rate of benthic respiration had become limited with respect to oxygen. Significant rates of oxygen uptake could usually be determined within 4 h at temperatures as low as $5^{\circ} \mathrm{C}$.

The water column in each tube was stirred with an induction motor driving a magnetic follower (Rank Brothers Ltd, Cambridge, UK). Preliminary experiments showed that benthic $\mathrm{O}_{2}$ uptake was unaffected by stirring rates over the range 300 to $900 \mathrm{rpm}$, and stirring during the experiments was at $300 \mathrm{rpm}$.

Nutrient exchange fluxes: At the end of the measurements of benthic oxygen uptake (usually $4 \mathrm{~h}$ ), the cores were uncapped and an initial volume $(100 \mathrm{ml})$ of water was removed to create a head space. The cores were then re-capped and an air stream which had been bubbled first through phosphoric acid $(0.1 \mathrm{M})$ to remove any gaseous ammonia (Sloth et al. 1992), and humidified by bubbling through water, was connected to the cap of each core. The humidified air stream completely re-aerated and mixed the water column.

A water sample $(20 \mathrm{ml})$ was taken from each core tube through a sample port to measure solute concentrations at the beginning of the incubation period $\left(C_{0}\right)$. The cores were then incubated for up to $16-24 \mathrm{~h}$ when a water sample $(20 \mathrm{ml})$ was taken to measure final solute concentrations $\left(C_{1}\right)$. All water samples were filtered through glass fibre filters (GF/F, Whatman Ltd, Maidstone, UKJ and frozen at $-20^{\circ} \mathrm{C}$ until analysed. Triplicate core tubes containing only site water [300 ml), with no sediment present, were treated, aerated and incubated as above, to act as controls for water column processes in the absence of sediment/water exchange. Any changes of solute concentrations in the control tubes without sediment $\left(W_{t}-W_{0}\right)$ were deducted from changes in the core tubes with sediment $\left(C_{1}-C_{0}\right)$ to deduce the net changes due solely to sediment/water fluxes.

On each occasion the exchange rates of nitrate, nitrite, ammonium, silicate and phosphate across the sediment-water interface were measured. It has been reported (Lomstein et al. 1989, Pedersen et al. 1993) that urea can be a significant product of organic matter degradation in sediments, constituting $47 \%$ of the total dissolved $\mathrm{N}$ flux (urea $+\mathrm{NH}_{4}{ }^{+}+\mathrm{NO}_{3}{ }^{-}+\mathrm{NO}_{2}{ }^{-}$) from shallow water Bering Shelf sediments. On 2 occasions in June and July 1994, water samples at the beginning and end of the sediment core incubations were also analysed for urea at Site 4.

Sedimentary rates of sulphate reduction: To measure the rates of sulphate reduction 4 vertical cores of sediment were collected from each site in small perspex core tubes $(20 \mathrm{~cm}$ long $\times 2.4 \mathrm{~cm}$ inner diameter $)$. Each core tube was drilled with injection ports at $1 \mathrm{~cm}$ intervals, sealed with silicon sealer (Dow-Corning Chemicals Ltd, Hounslow, UK). Each core was injected at $1 \mathrm{~cm}$ intervals down to $15 \mathrm{~cm}$ with sodium ${ }^{35} \mathrm{~S}$-sulphate solution $[10 \mu \mathrm{l} ; 11.1 \mathrm{kBq}(0.3 \mu \mathrm{Ci})$, sp. activity $38.6 \mathrm{TBq} \mathrm{mmol}{ }^{-1}$; Amersham International Ltd, Amersham, UK] made up in ultra high purity (UHP) water. One core from each site was immediately fixed as a $T_{0}$ control (see below) and the other 3 cores were incubated for 16 to $24 \mathrm{~h}$ at in situ temperature

The entire core was then dumped into zinc acetate solution (100 $\mathrm{ml}$ of $5 \% \mathrm{w} / \mathrm{v})$, homogenised, reweighed and frozen at $-20^{\circ} \mathrm{C}$. Initially vertical profiles of sulphate reduction rates were measured. However, subsequently, the method was modified to permit the determination of the depth-integrated rate of sulphate reduction while reducing the number of samples to be processed.

After thawing the fixed sub-samples $(20 \mathrm{ml})$ of sediment were digested, as described in Nedwell et al. (1993b), to recover both acid-volatile sulphides (AVS) and tin-reducible sulphides (TRS); which includes pyrite (Skyring 1985, Nedwell \& Takii 1988). The hydrogen sulphide evolved from the digested samples was trapped in zinc acetate solution $(40 \mathrm{ml}$ of $1 \% \mathrm{w} / \mathrm{v})$.

The remaining digested slurry of each sediment sample was centrifuged, decanted off, and made up to $200 \mathrm{ml}$. Duplicate sub-samples from the zinc acetate traps $(2 \mathrm{ml})$ and the residual sediment digests $(0.12 \mathrm{ml}$ $+1.88 \mathrm{ml}$ UHP water) were added to scintillant $(2 \mathrm{ml}$ Instagel, Packard Instrument Co., Groningen, The Netherlands) and the radioactivity counted in a scintillation counter (Rackbeta, LKB, Broma, Sweden) with an external standard to correct for quenching. The rates of sulphate reduction were calculated according to Fossing \& Jørgensen (1989). 
A preliminary experiment was carried out to establish that the sulphate reduction rates measured in the sediment were linear with respect to time over the incubation period used. Triplicate cores from Site 4 were treated as above after $0,3,6,12$ and 24 h incubation.

Sedimentary sulphide concentrations: Following the removal from the zinc acetate traps of an aliquot for scintillation counting, the remainder of the zinc sulphide precipitate was used to determine the total sulphide content of the sediment samples by the methylene blue method (American Public Health Association 1976)

Vertical concentration profiles of nutrients: After the measurements of nutrient exchange fluxes the cores were extruded and sliced at $1 \mathrm{~cm}$ intervals for the 0 to $5 \mathrm{~cm}$ horizon, and at 9 to 10 and 14 to $15 \mathrm{~cm}$ depths. A sample (approx. $20 \mathrm{ml}$ ) from each segment was put in a $50 \mathrm{ml}$ syringe body, cut off at the $20 \mathrm{ml} \mathrm{mark,} \mathrm{with}$ the luer outlet covered by a glass fibre filter (GF/F, Whatman Ltd). A filter holder containing a second glass fibre filter was then screwed into the luer. The whole unit was placed on top of a plastic bijou bottle ( $7 \mathrm{ml}$; Bibby Sterilin, Stone, UK) inside a centrifuge tube and spun at $1050 \times g$ for $5 \mathrm{~min}$. The pore water sample was then frozen at $-20^{\circ} \mathrm{C}$ until analysed.

Analyses: Ammonium was analysed by the method of Harwood \& Kuhn (1970), urea by the method of Price \& Harrison (1987) and 'reactive' silicate according to the method of Parsons et al. (1984). Nitrate, nitrite, phosphate and sulphate were analysed by ion exchange chromatography (series $2000 \mathrm{i}$, Dionex Corp, Sunnyvale, CA, USA) with a $1.7 \mathrm{mM} \mathrm{NaHCO}_{3}$ and $1.8 \mathrm{mM} \mathrm{Na}_{2} \mathrm{CO}_{3}$ eluent, at a flow rate of $3 \mathrm{ml} \mathrm{min}^{-1}$ and a $0.07 \%$ solution $\left(\mathrm{V} / \mathrm{V}\right.$ ) of concentrated $\mathrm{H}_{2} \mathrm{SO}_{4}$ regenerant at a flow rate of $8 \mathrm{ml} \mathrm{min}{ }^{-1}$ Peak areas of samples were compared to those of known standards.

Sedimentary and water column nitrous oxide concentrations: Triplicate vertical sediment samples $(10 \mathrm{ml})$ were collected from each site using cut-off hy- podermic syringes $(2 \times 5 \mathrm{ml})$. Samples were transferred to glass bottles $(50 \mathrm{ml})$ containing $10 \mathrm{ml}$ of UHP water, sealed with a butyl rubber stopper and then frozen in dry ice. Water column and air samples $(20 \mathrm{ml})$ were also collected from each site. After shaking and equilibrating to room temperature, gas samples $(0.2 \mathrm{ml})$ were removed from the headspace of each sample using a gas-tight syringe (Dynatech, Precision Sampling Corporation, Baton Rouge, LA, USA) and injected into a gas chromatograph (Shimadzu GC 14A, Dyson Instruments, Washington, UK) equipped with a ${ }^{63} \mathrm{Ni}$ electron capture detector. Gases were separated on a glass column ( $4 \mathrm{~m} \times 2 \mathrm{~mm}$ ) packed with Porapak $\mathrm{Q}$ $60-80$ at $25^{\circ} \mathrm{C}$. The detection limit for $\mathrm{N}_{2} \mathrm{O}$ was $55 \mathrm{ppb}$ and was linear up to $10^{7} \mathrm{ppb}$. Peak areas of samples were compared to those of known standards. Nitrous oxide concentrations in the sediment pore water and column water were back-calculated from the headspace concentration according to Weiss \& Price (1980).

\section{RESULTS}

\section{Sediment characteristics}

The characteristics of the sediments at the 4 sites are shown in Table 1. In all cases the sediments were predominantly very fine sand (see Wentworth classification of particle sizes; Tait 1983). Sediment at Site 1 had a higher content of very fine sand and of silt/clay than the other sites in the top 1 to $5 \mathrm{~cm}$ fraction. Site $2 \mathrm{had}$ equal amounts of fine and very fine sands in the top 1 to $5 \mathrm{~cm}$ fraction and the overall lowest silt/clay fraction. Although porosity and specific gravity varied with depth there was no overall trend. Mean annual values for porosity (Table 1) clearly show that there was minimal spatial or temporal variation throughout the upper estuary. The organic C content at Site 1 was also greatest, with the lowest sedimentary $\mathrm{C}: \mathrm{N}$ ratio. There was no statistically significant difference in the sedimen-

Table 1. Sediment characteristics, summer/winter oxygen penetration maxima and mean sulphide content for the 4 sites investıgated between December 1992 and November 1993 in the Great Ouse estuary, UK

\begin{tabular}{|c|c|c|c|c|c|c|c|c|c|}
\hline \multirow[t]{2}{*}{ Site } & \multicolumn{3}{|c|}{$\begin{array}{l}\% \text { of top } 5 \mathrm{~cm} \\
\text { of sediment }\end{array}$} & \multirow[t]{2}{*}{$\begin{array}{l}\text { Mean } \\
\text { porosity }^{d}\end{array}$} & \multirow{2}{*}{$\begin{array}{l}\text { Mean organic } \\
\text { carbon } \\
(\% \text { dry wt })^{e}\end{array}$} & \multirow[t]{2}{*}{$\begin{array}{l}\text { Mean } \mathrm{C}: \mathrm{N} \\
\text { ratio }(\mathrm{g}: \mathrm{g})^{*}\end{array}$} & \multicolumn{2}{|c|}{$\begin{array}{c}\mathrm{Max} \mathrm{O}_{2} \text { penetration } \\
(\mathrm{mm})\end{array}$} & \multirow[t]{2}{*}{$\begin{array}{l}\text { Mean sulphide content } \\
(\mu \mathrm{mol} \mathrm{cm} \text { " wet sed })^{h}\end{array}$} \\
\hline & $\mathrm{FS}^{\mathrm{d}}$ & VES' & $S^{r}$ & & & & $\operatorname{Jan}, 4^{\circ} \mathrm{C}$ & Aug, $18^{\circ} \mathrm{C}^{9}$ & \\
\hline 1 & 7 & 76 & 17 & $0.55 \pm 0.02$ & $1.81 \pm 0.12$ & $24: 1 \pm 1.0$ & 5.5 & 1.75 & $6.9 \pm 1.3$ \\
\hline 2 & 47 & 48 & 5 & $0.46 \pm 0.01$ & $1.42 \pm 0.17$ & $31: 1 \pm 2.0$ & 9.5 & 3.25 & $7.2 \pm 3.1$ \\
\hline 3 & 26 & 71 & 3 & $0.50 \pm 0.02$ & $1.21 \pm 0.12$ & $35: 1 \pm 2.0$ & 5.5 & 2.75 & $27.2 \pm 8.2$ \\
\hline 4 & 32 & 58 & 10 & $0.51 \pm 0.01$ & $1.12 \pm 0.12$ & $28: 1 \pm 1.0$ & 4.5 & 5.25 & $9.6 \pm 2.1$ \\
\hline \multicolumn{10}{|c|}{ 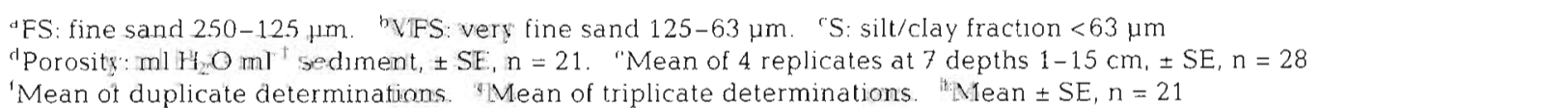 } \\
\hline
\end{tabular}


tary organic C content with either depth or season, and the values given in Table 1 are representative averages for both depth and time. The total $N$ content of the sediment was significantly $(p<0.05)$ positively correlated to the organic $\mathrm{C}$ content.

Sites 1 and 2 were essentially freshwater sites to which penetration of seawater rarely occurred (Fichez et al. 1992). The annual high water salinity range at Site 1 was 0.25 to $0.62 \%$ (JoNuS data base) and the salinity of the sediment pore water was always $<3 \%$ at Site 2 and always $<2 \%$ at Site 1 . Seawater penetrated to Site 4 on every high tide and the annual high water salinity range was 0.51 to $18.86 \%$ (JoNuS data base). Pore water salinity values reached $25 \%$ at Site 4 and $8 \%$ at Site 3 . Whilst all the sites were intertidal, Sites 3 and 4 could be regarded brackish, whereas Sites 1 and 2 were essentially tidal freshwater.

\section{Dissolved $\mathrm{O}_{2}$}

Measurements in the river water showed that dissolved $\mathrm{O}_{2}$ was always close to air-saturation. Even in summer when water temperature was highest $\left(22^{\circ} \mathrm{C}\right)$ and river flow low $\left(10.5 \mathrm{~m}^{3} \mathrm{~s}^{-1}\right)$ the dissolved $\mathrm{O}_{2}$ was always $>80 \%$ of the air-saturation value. Dissolved $\mathrm{O}_{2}$ could be measured only within the top few mm of the sediment (Table 1). Penetration of $\mathrm{O}_{2}$ was usually least at Site 1, which had the highest benthic organic content. Oxygen penetration into the sediment was generally less during summer than in winter, when the rate of benthic biological respiration decreased (see Figs. 6 \& 7). The sediment at Site 2 appeared thixotropic, with a subsurface throughflow of water, and this coincided with deeper penetration of dissolved $\mathrm{O}_{2}$ measured at this site

\section{Nitrate and ammonium concentrations}

Seasonal differences in the rainfall pattern influenced the river flow (Fig. 2a), with greatly increased TON flux to the estuary from $7.8 \times 10^{6} \mathrm{~mol} \mathrm{mo}^{-1}$ in August to $140.6 \times 10^{6} \mathrm{~mol} \mathrm{mo}{ }^{-1}$ during November (National Rivers Authority unpubl. data). Nitrate was always by far the dominant form of inorganic nitrogen and its concentrations were always higher in the river water than in the sediment pore water, indicating that the sediments at all sites were consistently sinks for $\mathrm{NO}_{3}{ }^{-}$. Fig. $2 \mathrm{~b}$ shows the nitrate concentrations at Site 4 and illustrates the seasonal changes which occurred. There was a significant correlation between water column nitrate concentration and nitrate in the top 0 to $1 \mathrm{~cm}$ of sediment. The pore water $\mathrm{NO}_{3}{ }^{-}$pool within the top $1 \mathrm{~cm}$ of sediment at Site 4 would have been
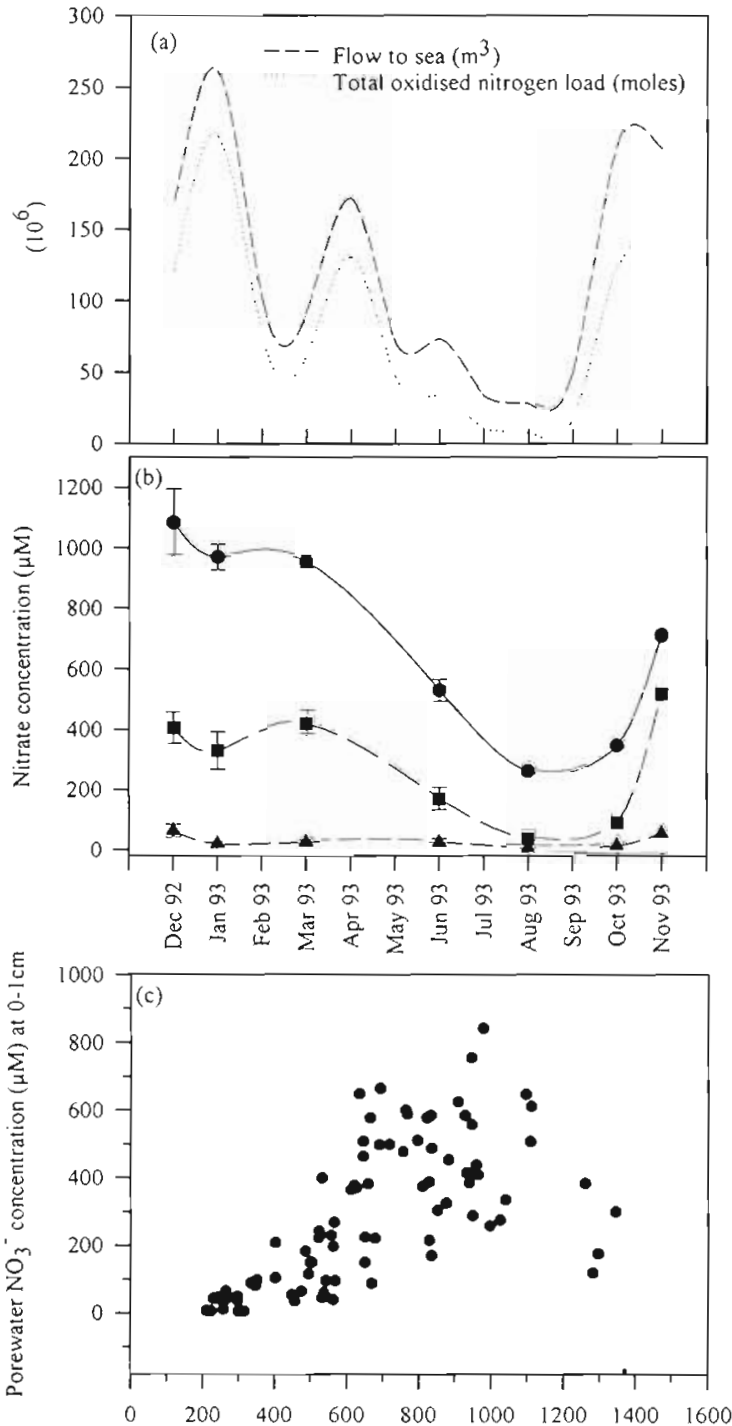

Overlying water column $\mathrm{NO}_{3}{ }^{-}$concentration $(\mu \mathrm{M})$

Fig. 2. (a) Monthly total flow rates and monthly Total Oxidised Nitrogen loads for the Great Ouse between December 1992 and November 1993 (National Rivers Authority unpubl. data). (b) Column water nitrate concentrations ( ) and pore water nitrate concentrations at 0 to $1 \mathrm{~cm}(\boldsymbol{\nabla})$ and 1 to $2 \mathrm{~cm}(\mathbf{\Delta})$ into the sediment at Site 4 between December 1992 and November 1993. Bars indicate standard error, $n=3$. (c) Scatter plot of overlying water column nitrate concentrations against pore water nitrate concentrations $(0$ to $1 \mathrm{~cm}) ; \mathrm{r}=0.63, \mathrm{p}<0.05$.

(-) Mean of triplicate measurements at all 4 sites from December 1992 to November 1993

$3004 \mu \mathrm{mol} \mathrm{m} \mathrm{m}^{-2}$ in November, compared to only $172 \mu \mathrm{mol} \mathrm{m} \mathrm{m}^{-2}$ during the much lower flow conditions in August. When all sites were pooled, the pore water $\mathrm{NO}_{3}{ }^{-}$concentrations (and hence $\mathrm{NO}_{3}{ }^{-}$pool size) within the top $1 \mathrm{~cm}$ of sediments were significantly $(\mathrm{p}<0.05)$ positively correlated with the overlying $\mathrm{NO}_{3}{ }^{-}$concentrations in the water column (Fig. 2c). However, the 


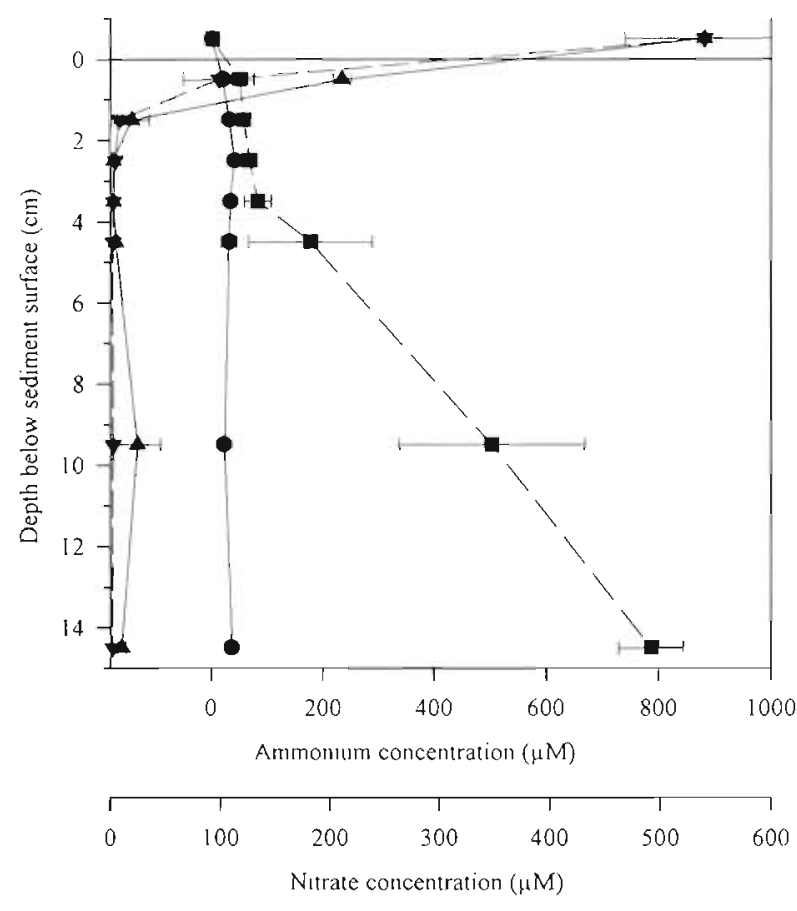

Fig. 3. Nitrate pore water profiles for sediment collected from Sites $1(\nabla)$ and $2(\mathbf{\Lambda})$ and ammonium pore water profiles for sediment collected from Sites 1 ( ) and 2 (@) durng October 1993, sediment temperature $9^{\circ} \mathrm{C}$. Bars indicate standard error, $n=3$. Values above zero denote concentration in the overlying water

relationship disappeared beyond $1 \mathrm{~cm}$ into the sediment, indicating that the majority of the $\mathrm{NO}_{3}{ }^{-}$pool was confined near the sediment surface, and was derived from intrusive $\mathrm{NO}_{3}{ }^{-}$and not from internal nitrification.

Nitrite concentrations in both the river water and sediment pore waters were always negligible, and are not reported further.

In contrast, $\mathrm{NH}_{4}{ }^{+}$concentrations were always greater in the sediment pore water than in the water column (Fig. 3), indicating that the sediments at all sites were potential sources of $\mathrm{NH}_{4}{ }^{+}$. For example, in October 1993, the $\mathrm{NH}_{4}{ }^{+}$concentration increased linearly with depth at Site $1\left(\mathrm{r}^{2}=0.97\right)$ from $50 \mu \mathrm{M}$ at $0.5 \mathrm{~cm}$ to $800 \mu \mathrm{M}$ at $14.5 \mathrm{~cm}$ (Fig. 3), and similar $\mathrm{NH}_{4}{ }^{+}$ profiles were recorded at Sites 3 and 4 . However, Site 2 seemed to be unusual in that the pore water $\mathrm{NH}_{4}{ }^{*}$ concentrations tended to be much lower than at the other sites, although the $\mathrm{NO}_{3}{ }^{-}$concentrations were similar (Fig. 3).

\section{Nutrient exchange rates}

At Sites 1,3 and 4 the nutrient exchange data confirmed that the sediments were consistent sinks for $\mathrm{NO}_{3}{ }^{-}$(Fig. 4) and sources for $\mathrm{NH}_{4}{ }^{+}$(Fig. 5). Site 2 was

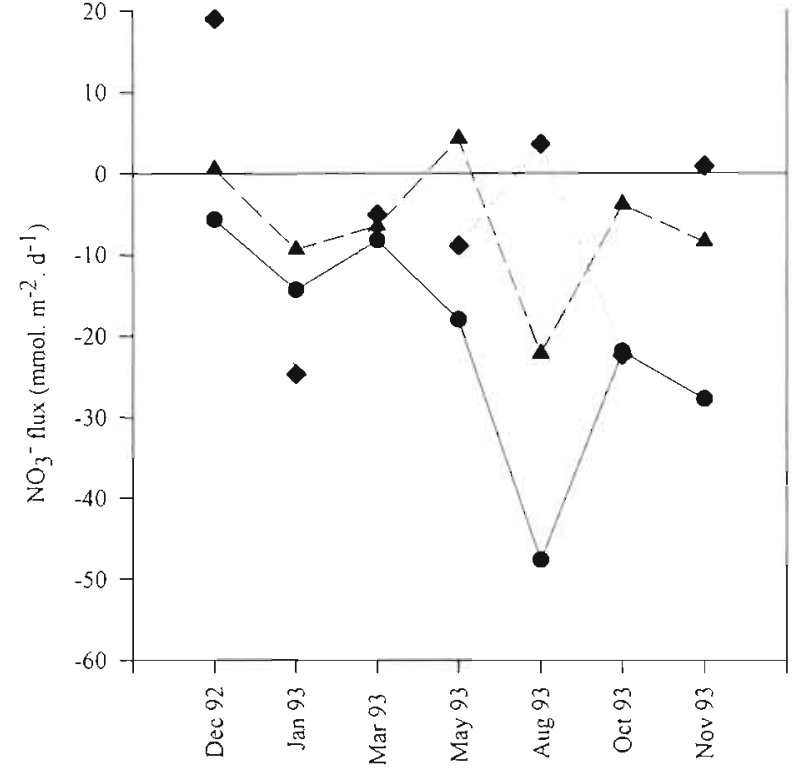

Fig. 4. Nitrate flux across the sediment/water interface at Sites $1(\bullet), 3(\Delta)$ and $4(\bullet)$. Negative values indicate uptake by the sediment. Means of 3 replicates: error bars have been omitted to aid clarity

an exception as, while the sediment concentration profiles indicated that it should be a sink for $\mathrm{NO}_{3}$ (Fig. 3) and a source for $\mathrm{NH}_{4}{ }^{+}$(Fig 3), no statistically significant exchange fluxes were measured for $\mathrm{NO}_{3}{ }^{-}$. The flux of $\mathrm{NO}_{3}{ }^{-}$into all the sediments was, on average, an

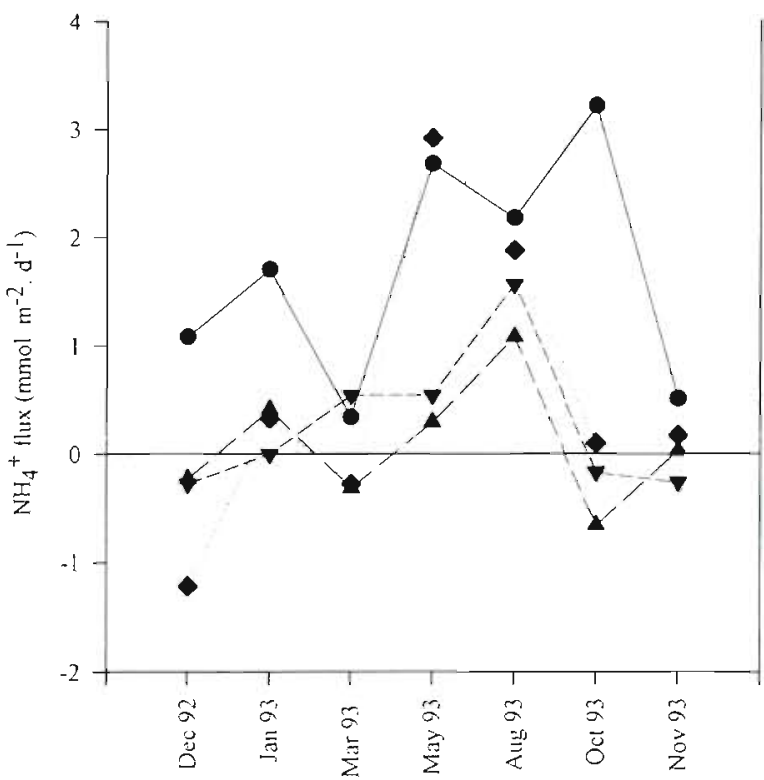

Fig. 5. Ammonium flux across the sediment/water interface at Sites $1(\bullet), 2(\mathbf{\nabla}), 3(\mathbf{\Delta})$ and $4(\bullet)$. Positive values indicate release from the sediment. Means of 3 replicates: error bars have been omitted to aid clarity 
Table 2. Annual sedimentary budgets of nutrients exchanged, electron ( $e^{-}$) acceptors utilised and the \% of the total oxygen budget (based on stoichiometry; see text) used in sulphide reoxidation

\begin{tabular}{|c|c|c|c|c|c|c|}
\hline Site & $\begin{array}{l}\text { Annuc } \\
\mathrm{NO}_{3}\end{array}$ & $\begin{array}{l}\text { rchange } \\
\mathrm{NH}_{4}{ }^{+}\end{array}$ & $\begin{array}{l}\text { lxes }(\mathrm{mo}) \\
\mathrm{SiO}_{4}{ }^{2-}\end{array}$ & $\begin{array}{l}\mathrm{m}^{-2} \mathrm{yr}^{-1} \mathrm{~J}^{\mathrm{a}} \\
\mathrm{O}_{2} \text { uptake }\end{array}$ & $\begin{array}{l}\text { Annual sulphate reduction rate } \\
\qquad\left(\mathrm{mol} \mathrm{SO}_{4}{ }^{2-} \mathrm{m}^{-2} \mathrm{yr}^{-1}\right)^{\mathrm{b}}\end{array}$ & $\begin{array}{l}\% \text { of annual oxygen budget } \\
\text { used for sulphide reoxidation }\end{array}$ \\
\hline 1 & -2.54 & 0.36 & 0.38 & -12.84 & 5.31 & 83 \\
\hline 2 & 0.00 & 0.16 & 0.12 & -15.69 & 0.16 & 2 \\
\hline 3 & -1.98 & 0.08 & -0.31 & -28.01 & 6.05 & 43 \\
\hline 4 & -6.83 & 0.64 & -1.46 & -23.43 & 3.69 & 31 \\
\hline
\end{tabular}

order of magnitude greater than the $\mathrm{NH}_{4}{ }^{+}$flux from the sediment, and the sediments were thus acting as net sinks for dissolved inorganic $\mathrm{N}$ from the water column. The flux of $\mathrm{NO}_{3}{ }^{-}$into the sediments showed no clear seasonal pattern and was on average (Sites 1, 3 and 4) $450 \mu \mathrm{mol} \mathrm{NO}{ }^{-} \mathrm{m}^{-2} \mathrm{~h}^{-1}$. There was no statistically significant correlation between the measured rates of $\mathrm{NO}_{3}{ }^{-}$exchange and the $\mathrm{NO}_{3}{ }^{-}$concentration in the overlying water, which suggested that for the majority of the year the $\mathrm{NO}_{3}{ }^{-}$exchange rates were maximal and saturated with $\mathrm{NO}_{3}{ }^{-}$(annual mean upper estuary $\mathrm{NO}_{3}{ }^{-}$ concentration $700 \mu \mathrm{M}$; JoNuS data base). There was also no statistically significant correlation between $\mathrm{NO}_{3}{ }^{-}$exchange and sediment temperature. Maximum $\mathrm{NH}_{4}{ }^{+}$release from the sediments occurred during summer (Fig. 5) when organic degradation rates were maximal and the depth of the oxic layer least. Pooling the $\mathrm{NH}_{4}{ }^{+}$flux data for all 4 sites revealed an overall statistically significant correlation between the $\mathrm{NH}_{4}^{+}$flux from the sediment and the sediment temperature $(p<$ $0.05)$

Statistically significant fluxes of nitrite were never detected at any site. There were no significant exports of urea from the sediments at Site 4 during June and July 1994.

\section{Annual fluxes across the sediment-water interface}

The measured rates of solute exchange across the sediment-water interface were integrated with respect to time to derive the annual fluxes (Table 2). On an annual basis Sites 1, 3, and 4, but not 2, were sinks for $\mathrm{NO}_{3}{ }^{-}$and sources for $\mathrm{NH}_{4}{ }^{+}$. The marine-influenced Sites 3 and 4 were sinks for silicate, but the freshwater Sites 1 and 2 were exporters of silicate; a difference between marine and freshwater sediments which has been reported elsewhere (Balls 1994). Phosphate was only detectable over the summer and autumn months with a mean water column concentration of $9 \mu \mathrm{M}$ for the 4 sites. Exchange fluxes were variable and the sediments were neither consistently sinks nor sources of $\mathrm{PO}_{4}{ }^{3-}$.

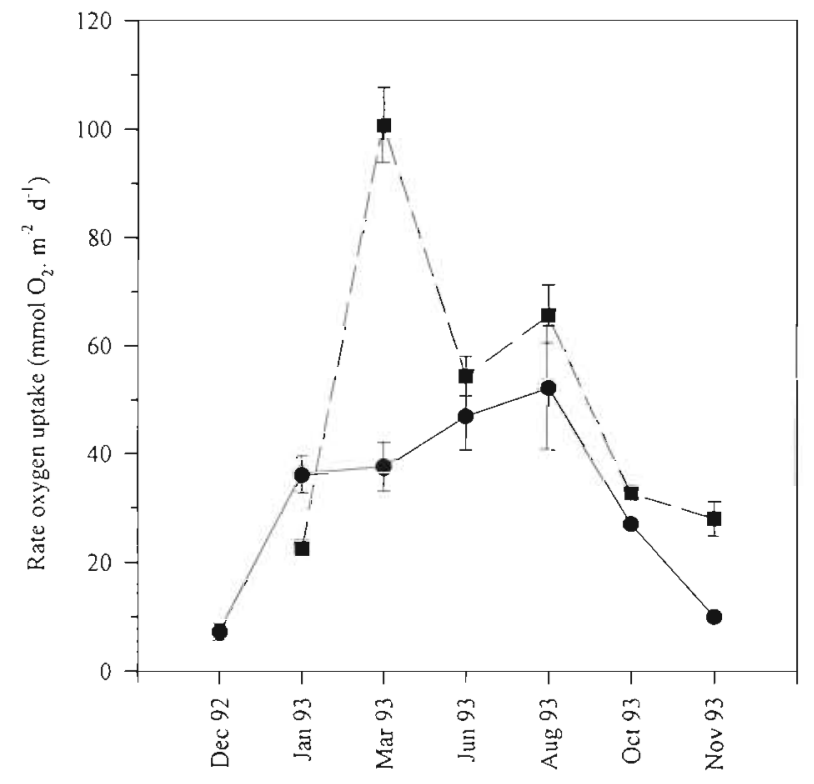

Fig. 6. Oxygen uptake across the sediment/water interface at Site $1(0)$ and Site $4(\mathbb{\square})$. December 1992 data omitted from Site 4 ; see text. Bars indicate standard error, $\mathrm{n}=3$

\section{Benthic $\mathrm{O}_{2}$ uptake}

Oxygen uptake rates by the sediments were significantly correlated to the sediment temperature during $1992-1993$ at Sites 1 and $2(\mathrm{p}<0.05, \mathrm{r}=0.784$ and 0.876 , respectively), but further downstream there was no significant correlation with seasonal temperature at Sites 3 and 4 . This would suggest that environmental factors other than temperature were more important in regulating oxygen uptake at the downstream estuarine sites. During December 1992, anomalously high $\mathrm{O}_{2}$ uptake rates were measured at Sites 3 and 4 , for which we have no explanation, although we may speculate that it was the result of organic discharge from the sugar beet mill located between these 2 sites. When all of the sedimentary oxygen uptake data were considered together (for the 4 sites in the upper estuary, omit- 
ting December 1992 at Sites 3 and 4) a significant ( $p<$ $0.05)$ positive correlation was found between the rate of sedimentary oxygen uptake and seasonal temperature. Fig. 6 illustrates the seasonal pattern of oxygen uptake at Sites 1 and 4 . There was no detectable seasonal cycle at Site 4 during 1993 but measurements were continued for an additional year (1994), and during the second season $\mathrm{O}_{2}$ uptake did show a seasonal trend, correlated significantly $(p<0.05)$ with the sediment temperature (data not shown).

The annual benthic $\mathrm{O}_{2}$ uptake for each site (Table 2) was calculated by integration of the measured rates with respect to time. At Site 4 there were 2 yr of $\mathrm{O}_{2}$ uptake measurements (only 1 yr of data shown in Fig. 6) and, despite any interannual differences, the annual values for 1992-1993 and 1994-1995 were virtually identical ( 23 and $21 \mathrm{~mol} \mathrm{O}_{2} \mathrm{~m}^{-2}$ ). This suggested relatively consistent annual budgets.

\section{Sulphate}

There was no clear seasonal pattern to the concentrations of $\mathrm{SO}_{4}{ }^{2-}$ measured in the estuary. The concentrations of $\mathrm{SO}_{4}{ }^{2-}$ were very similar along the entire length of the estuary at low tide, ranging (annual mean) from $1.7 \mathrm{mM}$ at the freshwater end to $2.8 \mathrm{mM}$ at the seaward end. The mean annual pore water $\mathrm{SO}_{4}{ }^{2-}$ concentration for the most seaward Site 4 (King's Lynn), where pore water salinity values of up to $25 \%$ were recorded, was $7.7 \pm 2.2 \mathrm{mM}$ (SE). In contrast, at Site 1 (Denver Sluice), where pore water salinity values never exceeded $2 \%$, the mean $\mathrm{SO}_{4}{ }^{2-}$ concentration was only $1.2 \pm 0.3 \mathrm{mM}$ (SE). Generally, in the summer months the pore water concentrations of $\mathrm{SO}_{4}{ }^{2-}$ declined with increased depth, indicating net removal of $\mathrm{SO}_{4}{ }^{2-}$ within the sediment. The $\mathrm{SO}_{4}{ }^{2-}: \mathrm{S} \%$ ratios calculated for Site 4 (during August 1993) showed that at $2 \mathrm{~cm}$ into the sediment the $\mathrm{SO}_{4}{ }^{2-} \mathrm{S} \%$ ratio was $764: 1$ when normalised to $15 \%$ salinity, whereas at $15 \mathrm{~cm}$ into the sediment the $\mathrm{SO}_{4}{ }^{2-}: \mathrm{S} \%$ ratio was $11: 1$ at $15 \%$ salinity, indicating a net removal of $\mathrm{SO}_{4}{ }^{2-}$ with increased depth.

\section{Sulphate reduction rates}

At Sites 2 and 4 the sulphate reduction rates were significantly correlated with the sediment temperature ( $\mathrm{p}<0.05, \mathrm{r}=0.574$ and 0.681 , respectively), but not at Sites 1 and 3 . The seasonal trend for Site 4 is illustrated in Fig. 7. Despite the differences in $\mathrm{SO}_{4}{ }^{2-}$ concentrations at Sites 1 and 4 , the annual rates of sulphate reduction (Table 2) were very similar: 5.3 and $3.7 \mathrm{~mol}$ $\mathrm{SO}_{4}{ }^{2-} \mathrm{m}^{-2} \mathrm{yr}^{-1}$, respectively.

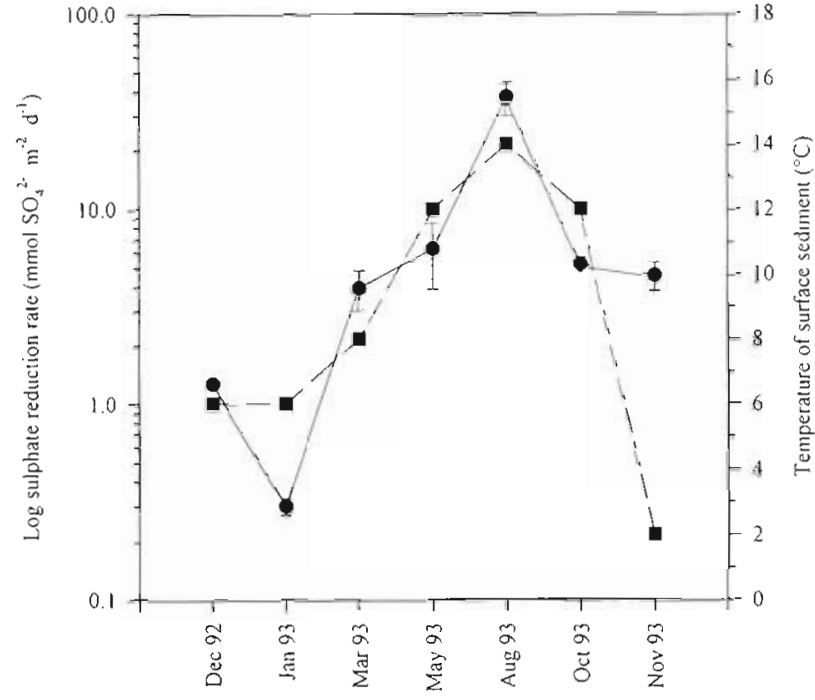

Fig. 7 Sediment sulphate reduction tates $(\bullet)$ and sediment temperature ( $\square$ ) at Site 4 . Bars indicate standard error, $n=3$

\section{Sedimentary sulphide concentrations}

The mean annual sulphide concentrations were of a similar order of magnitude at each site (Table 1). There was a significant $(p<0.05)$ positive correlation between the sediment temperature and sediment sulphide concentration at Sites 1 and $4(r=0.77$ and 0.70 , respectively), with maximal concentrations during August 1993. Sediment sulphide concentrations were

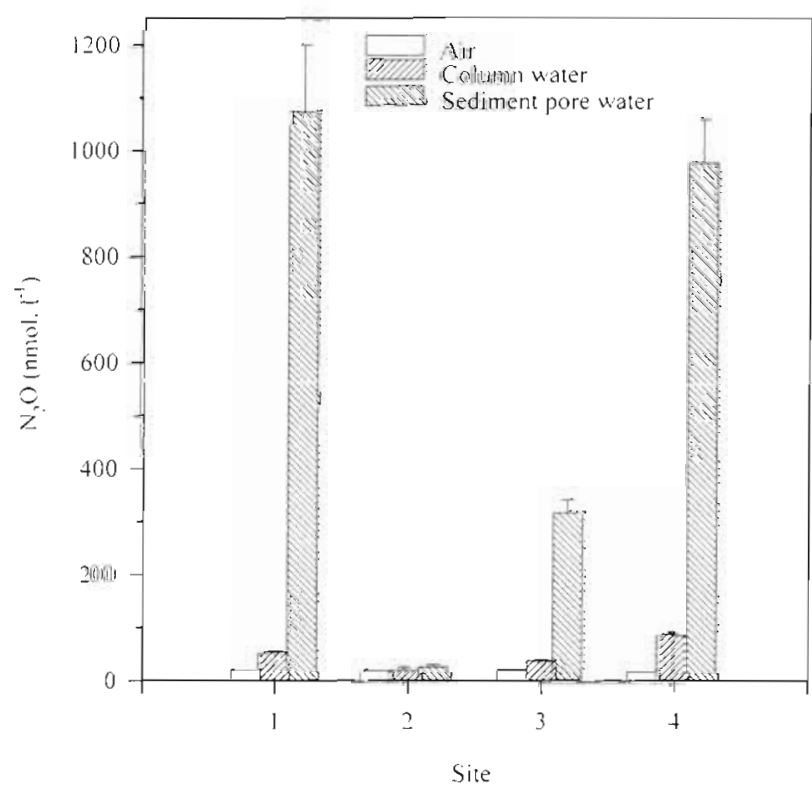

Fig. 8. Nitrous oxide concentrations determined in the aur, water and sediment pore water at all 4 sites 
significantly $(p<0.05)$ positively correlated with sulphate reduction rates at Site $4(r=0.92)$ but not at any of the other sites.

\section{Sedimentary and water column nitrous oxide concentrations}

The concentrations of $\mathrm{N}_{2} \mathrm{O}$ in the sediment pore water were highest at Sites 1 and $4(1074$ and $979 \mathrm{nmol}$ $\mathrm{N}_{2} \mathrm{O} \mathrm{l}^{-1}$ of pore water; Fig. 8) and lowest at Site 2 (28 nmol $\mathrm{N}_{2} \mathrm{O} \mathrm{I}^{-1}$ of pore water). The sediment and water column at Sites 1, 3 and 4 were all significantly $(p<0.05)$ supersaturated with $\mathrm{N}_{2} \mathrm{O}$ indicating that these sites were sources of $\mathrm{N}_{2} \mathrm{O}$. Site 2 was not a significant source of $\mathrm{N}_{2} \mathrm{O}$.

\section{DISCUSSION}

The organic $\mathrm{C}$ content of the Great Ouse sediments (range 1.12 to 1.81 organic $\mathrm{C} \%$ dry wt; Table 1) fell within the range reported for predominantly sandy sediments (Jørgensen \& Sørensen 1985, Brotas et al. 1990, Yoon \& Benner 1992). The significant positive correlation $(p<0.05)$ of total $N$ content of the sediment to organic $C$ content suggested that the $N$ was organically bound, corroborated by the fact that the measured sedimentary pool of dissolved inorganic $\mathrm{N}$ could account for $<1$ to $2 \%$ of the total sedimentary $\mathrm{N}$.

The profiles of dissolved $\mathrm{O}_{2}$ in the surface sediments all showed rapid depletion within the top $10 \mathrm{~mm}$ of sediment. At Site 2 the thixotropic nature of the sediment, and deeper $\mathrm{O}_{2}$ penetration (Table 1), suggested possible sub-surface irrigation of the sediment. The measured exchange fluxes of solutes across the sediment-water interface showed that, with the exception of Site 2, the sediments were similar to other estuarine sediments in being sinks for $\mathrm{NO}_{3}{ }^{-}$(Billen et al. 1985 Jørgensen \& Sørensen 1985, 1988, Binnerup et al. 1992, Watson et al. 1993) and sources of $\mathrm{NH}_{4}{ }^{+}$(Nedwell) 1982, Blackburn \& Henriksen 1983, Hopkinson 1987, Nedwell et al. 1993a, Watson et al. 1993). The $\mathrm{NO}_{3}$ concentrations in the pore water at Site 2 were similar to those at the other sites although there were much lower concentrations of pore water $\mathrm{NH}_{4}{ }^{+}$, suggesting that nitrification may have been active in this more oxic sediment.

The mean daily rates of $\mathrm{O}_{2}$ uptake by the Great Ouse sediments ( 35 to $77 \mathrm{mmol} \mathrm{O} \mathrm{m}^{-2} \mathrm{~d}^{-1}$ ) reflected those reported in other estuaries (Jørgensen \& Sørensen 1985, Binnerup et al. 1992) and shallow coastal seas (Upton et al. 1993). Although sedimentary organic C was greatest at Site 1 (Table 1) the rate of oxygen consumption at this site was the lowest (Table 2). How- ever, sedimentary organic $\mathrm{C}$ determinations do not discriminate between the amounts of labile or refractory organic matter present (Nedwell 1987) and thus may give little indication to the amount of microbially available organic matter at each site.

Despite the fact that the salinity measurements showed the estuary to be entirely freshwater at low tide, the $\mathrm{SO}_{4}{ }^{2-}$ concentrations (annual mean 1.7 to $2.8 \mathrm{mM}$ ) were relatively high. As freshwater $\mathrm{SO}_{4}{ }^{2-}$ concentrations are usually in the range 0.01 to $0.2 \mathrm{mM}$ (Ingvorsen \& Jorgensen 1984), the concentrations reported here indicated an upstream source of $\mathrm{SO}_{4}{ }^{2-}$. The range of sulphate reduction rates (10.1 to $16.6 \mathrm{mmol} \mathrm{SO}_{4}^{2-} \mathrm{m}^{-2} \mathrm{~d}^{-1}$ ) was similar to other estuaries and coastal seas (Jørgensen \& Sørensen 1985, Skyring 1985, Tuttle \& Roden 1993, Upton et al. 1993). The magnitude of sulphate reduction at the tidal freshwater Site 1 was similar to that at the brackish Site 4, despite the much smaller sedimentary sulphate pool at Site 1. Bak \& Pfennig (1991) pointed out that high rates of freshwater $\mathrm{SO}_{4}{ }^{2-}$ reduction can result in very fast turnover times of the sedimentary sulphate pool in lake sediment, reporting maximum rates of up to $1800 \mathrm{nmol} \mathrm{SO}_{4}{ }^{2-} \mathrm{cm}^{-3} \mathrm{~d}^{-1}$, which corresponded to a turnover of the $\mathrm{SO}_{4}^{2-}$ pool in $\sim 2 \mathrm{~h}$. Rapid depletion of the sulphate pool could cause underestimates of $\mathrm{SO}_{4}{ }^{2-}$ reduction rates, but the maximum sulphate reduction rate at Site 1 was equivalent to a turnover time for the sulphate pool of $1 \mathrm{~d}$. This was greater than the average incubation time used in our study, and corroborated the linearity of sulphate reduction rates measured over $24 \mathrm{~h}$ in our preliminary experiments. At Site 4 , in contrast, the turnover time for the sulphate pool was equivalent to $13 \mathrm{~d}$ during the summer. The lowest pore water sulphate concentration $(160 \mu \mathrm{M})$ recorded at Site 1 was well above the reported $k_{\mathrm{m}}$ values for $\mathrm{SO}_{4}{ }^{2-}$ of $5 \mu \mathrm{M}$ for a freshwater Desulfovibrio vulgaris and $77 \mu \mathrm{M}$ for a marine $D$. salexigens (Ingvorsen \& Jørgensen 1984). Low half saturation constants for $\mathrm{SO}_{4}{ }^{2-}$ uptake may explain why high rates of $\mathrm{SO}_{4}{ }^{2-}$ reduction have been recorded in freshwater environments such as Lake Constance (Bak \& Pfennig 1992), and further emphasise that $\mathrm{SO}_{4}{ }^{2-}$ reduction can be of quantitative significance in the mineralisation of organic matter, even in freshwater sediments.

The sedimentary sulphide concentrations $(7$ to $27 \mu \mathrm{mol} \mathrm{S} \mathrm{cm}{ }^{-3}$; Table 1) were similar to those reported for lake sediments $\left(-3\right.$ to $40 \mu \mathrm{mol} \mathrm{S} \mathrm{cm}^{-3}$; Jones \& Simon 1981, Bak \& Pfennig 1991), but lower than those reported for marine-dominated saltmarsh sediments ( 100 umol S cm${ }^{-3}$; Nedwell \& Takii 1988). The fact that sulphide did not accumulate within the sediments, at least on an annual basis, suggests that it was reoxidised. 


\section{Sedimentary nutrient budgets}

The measured annual rates of $\mathrm{O}_{2}$ and $\mathrm{NO}_{3}^{-}$uptake by the sediments, and the rates of sulphate reduction, can be used in conjunction with the $C$ and $N$ content of sedimentary organic matter measured at each site to calculate for each site a $\mathrm{C}$ and $\mathrm{N}$ budget, using the following stoichiometric equations.

(1) Oxygen respiration with $\mathrm{NH}_{4}{ }^{+}$liberation (Richards et al. 1965):

$\left(\mathrm{CH}_{2} \mathrm{O}\right)_{106}\left(\mathrm{NH}_{3}\right)_{16}+106 \mathrm{O}_{2}=106 \mathrm{CO}_{2}+16 \mathrm{NH}_{3}+106 \mathrm{H}_{2} \mathrm{O}$

(2) Oxygen respiration with coupled nitrification and denitrification of mineralised $\mathrm{NH}_{4}{ }^{+}$to $\mathrm{N}_{2}$ gas:

$\left(\mathrm{CH}_{2} \mathrm{O}\right)_{106}\left(\mathrm{NH}_{3}\right)_{16}+118 \mathrm{O}_{2}=106 \mathrm{CO}_{2}+8 \mathrm{~N}_{2}+130 \mathrm{H}_{2} \mathrm{O}$

(3) Nitrate respiration with mineralised $\mathrm{NH}_{4}{ }^{+}$oxidation to $\mathrm{N}_{2}$ gas (Richards et al. 1965):

$$
\begin{aligned}
\left(\mathrm{CH}_{2} \mathrm{O}\right)_{106}\left(\mathrm{NH}_{3}\right)_{16}+94.4 \mathrm{HNO}_{3} & = \\
106 \mathrm{CO}_{2} & +55.2 \mathrm{~N}_{2}+177.2 \mathrm{H}_{2} \mathrm{O}
\end{aligned}
$$

(4) Sulphate respiration with $\mathrm{NH}_{4}{ }^{+}$liberation (Richards et al. 1965):

$$
\begin{aligned}
& \left(\mathrm{CH}_{2} \mathrm{O}\right)_{106}\left(\mathrm{NH}_{3}\right)_{16}+53 \mathrm{SO}_{4}^{2-}= \\
& 106 \mathrm{CO}_{2}+53 \mathrm{~S}^{2-}+16 \mathrm{NH}_{3}+106 \mathrm{H}_{2} \mathrm{O}
\end{aligned}
$$

(5) Resulting sulphide was assumed to be completely reoxidised at the expense of oxygen (Schlegel 1975):

$$
\mathrm{H}_{2} \mathrm{~S}+2 \mathrm{O}_{2}=\mathrm{H}_{2} \mathrm{SO}_{4}
$$

Table 3 shows the proportion of the sedimentary organic $C$ mineralisation which can be accounted for by each electron ( $\mathrm{e}^{-}$) acceptor flux. At Sites 1, 3 and 4 the percentage of aerobic C oxidation (14 to $52 \%$ ) compares with 44 to $65 \%$ reported for Danish estuarine sediments (Jørgensen \& Sørensen 1985). However, at Site 2 oxygen respiration was the only significant process for organic matter mineralisation (reflecting the possible subsurface irrigation and better $\mathrm{O}_{2}$ penetration), accounting for $>98 \%$ of the organic $\mathrm{C}$ oxida- tion. At Sites 1, 3 and 4 proportionate organic mineralisation via denitrification was comparatively high (range 8 to $26 \%$ ), similar to values reported for Blelham Tarn, UK (Jones \& Simon 1980) but higher than the $4 \%$ reported for Danish freshwater sediments (Jorgensen \& Sørensen 1985). However the organic C content of the Danish sediments was an order of magnitude higher $(10.2 \%)$ than in the Great Ouse and where there is a high organic $\mathrm{C}: \mathrm{NO}_{3}{ }^{-}$ratio reduction of $\mathrm{NO}_{3}{ }^{-}$ to $\mathrm{NH}_{4}{ }^{+}$is favoured rather than denitrification ( $\mathrm{Ned}$ well 1982). The percentage $\mathrm{C}$ mineralisation via $\mathrm{SO}_{4}{ }^{2-}$ reduction decreased down the estuary, from Site 1 where $\mathrm{C}$ mineralisation via $\mathrm{SO}_{4}{ }^{2-}$ exceeded that via $\mathrm{O}_{2}$ (Table 3). Although this is unusual for a freshwater sediment, a higher percentage of $\mathrm{C}$ mineralisation via $\mathrm{SO}_{4}{ }^{2-}$ reduction has been reported before in the marine environment where the $\mathrm{SO}_{4}{ }^{2-}$ concentrations were high in intertidal salt marsh sediments (Howarth \& Teal 1979, Howarth \& Giblin 1983)

The same stoichiometric calculations applied to $\mathrm{C}$ also could be carried out to examine the fate of $\mathrm{N}$ fluxing through the sediment (Table 4), from both inorganic $\mathrm{N}$ transported into the sediment from the overlying water and inorganic $N$ released within the sediment by mineralisation of sedimentary organic matter (Table 3). Assuming that there was no significant net accumulation of $N$ within the sediment, the outputs of $N$ from the sediments must balance the inputs. [We did not measure $\mathrm{N}_{2}$ fixation, but in estuaries this tends to be a relatively unimportant part of the $N$ cycle (Capone 1988, Howarth et al. 1995), particularly in the presence of elevated nitrogen concentrations.] At Site 4 the measured annual sulphate reduction rate ( $\left.3.69 \mathrm{~mol} \mathrm{~m}^{-2} \mathrm{yr}^{-1}\right)$ could account stoichiometrically for the formation of $0.24 \mathrm{~mol}$ $\mathrm{NH}_{4}{ }^{+}$by mineralisation of sedimentary organic matter with the measured $\mathrm{C}: \mathrm{N}$ ratio (Table 3 ) with the concomitant formation of $3.69 \mathrm{~mol}$ of sulphide $\mathrm{m}^{-2} \mathrm{yr}^{-1}$. As a condition of the calculations it was assumed that all of

\begin{tabular}{|c|c|c|c|c|c|c|c|c|c|c|c|c|c|c|c|c|}
\hline \multirow[t]{2}{*}{ Site } & \multicolumn{2}{|c|}{$\begin{array}{l}\text { Sedimentary } \\
\text { organic C and } \\
N \text { content } \\
\left(\mathrm{mol} \mathrm{m}^{-2}\right)\end{array}$} & \multicolumn{3}{|c|}{$\begin{array}{l}\text { Annual } e^{-} \text {acceptor } \\
\text { reduction rates } \\
\left(\text { mol m-2 } \mathrm{yr}^{-1}\right)\end{array}$} & \multicolumn{4}{|c|}{$\begin{array}{l}\text { Stolchiometric } C \\
\text { mineralisation via } \\
\text { each e acceptor } \\
\left(\mathrm{mol} \mathrm{m} \mathrm{m}^{-2} \mathrm{yr}^{-1}\right)\end{array}$} & \multicolumn{3}{|c|}{$\begin{array}{c}\% \text { of organic C } \\
\text { degradation via each } \\
\text { e acceptor }\end{array}$} & \multicolumn{4}{|c|}{$\begin{array}{l}\text { Stoichiometric } \mathrm{N} \\
\text { muneralisation via } \\
\text { each e acceptor } \\
\text { (mol m} \mathrm{yr}^{-1} \text { ) }\end{array}$} \\
\hline & C & $N$ & $\mathrm{O}_{2}$ & $\mathrm{NO}_{3}$ & $\mathrm{SO}_{4}{ }^{2-}$ & $\mathrm{O}_{2}$ & $\mathrm{NO}_{3}{ }^{-1}$ & i) $\mathrm{SO}^{2-}$ & Total & $\mathrm{O}_{2}$ & $\mathrm{NO}_{3}^{-}$ & $\mathrm{SO}_{4}{ }^{2-}$ & $\mathrm{O}_{2}$ & $\mathrm{NO}_{3}{ }^{-1}$ & $802-$ & Total \\
\hline 1 & & & & & & & & & & 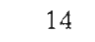 & 10 & & & & & \\
\hline 2 & 63 & 4.3 & & 0 & & & 0.0 & & & 98 & 0 & & & & & 0.27 \\
\hline 3 & .13 & 5.4 & & & & & & 12.10 & & 52 & 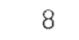 & 4 & & 0. & 3 & 0.60 \\
\hline 4 & 181.27 & 5.94 & 23.43 & 6.83 & 3.69 & 15.96 & 8.33 & 7.38 & 31.67 & 50 & 26 & 24 & 0.52 & 0.27 & 0.24 & 1.03 \\
\hline
\end{tabular}
the sulphide formed from sulphate reduction was re-

Table 3. Annual sedimentary organic matter content, reduction rates for each $\mathrm{e}^{-}$acceptor, $\mathrm{C}$ and $\mathrm{N}$ mineralisation rates via each $e^{-}$acceptor and \% of organic C mineralised via each e acceptor, for 4 sites in the Great Ouse estuary between December 1992 and November 1993

${ }^{a} 0-15 \mathrm{~cm} .{ }^{b} \mathrm{NO}_{3}{ }^{-}$reduction to nitrogen gas 
Table 4. Annual sediment nitrogen budget with nitrate bejng reduced to nitrogen gases

\begin{tabular}{|c|c|c|c|c|c|c|c|c|c|}
\hline Site & $\begin{array}{r}\text { Total } \\
\\
\mathrm{NO}_{3}\end{array}$ & $\begin{array}{c}\text { flux } t \\
\text { edime } \\
\mathrm{l} \mathrm{m}^{-2} y \\
\mathrm{~N} \\
\text { min }^{\prime}\end{array}$ & $\begin{array}{l}\text { hrough } \\
\text { nt } \\
\left.r^{-1}\right) \\
\text { Total } \\
\text { N flux }\end{array}$ & $\begin{array}{c}\text { Measured } \\
\mathrm{NH}_{4}^{+} \text {flux from } \\
\text { sediment } \\
\left(\mathrm{mol} \mathrm{m}^{-2} \mathrm{yr} \mathrm{r}^{\prime}\right)\end{array}$ & $\begin{array}{l}\mathrm{NH}_{\downarrow}^{+} \text {efflux } \\
\text { as } \% \text { of } \mathrm{N} \\
\text { flux }\end{array}$ & $\begin{array}{l}\therefore \% \text { of total } \\
\text { sedimentary } \\
\mathrm{N} \text { budget to } \\
\text { gases }\end{array}$ & $\begin{array}{c}\% \text { of } \mathrm{Ngas} \\
\text { flux from } \\
\text { coupled } \\
\text { N/D }\end{array}$ & $\begin{array}{c}\therefore \text { mineralised } \\
\mathrm{N} \text { disappearing } \\
\text { as gases } \\
\left(\mathrm{mol} \mathrm{m} \mathrm{m}^{-2} \mathrm{yr}^{-1}\right)\end{array}$ & $\begin{array}{c}\text { "\% mineralised } \\
N \text { disappearing } \\
\text { as gases }\end{array}$ \\
\hline 1 & 2.54 & 0.56 & 3.10 & 0.36 & 18 & 82 & 7 & 0.20 & 36 \\
\hline 2 & 0.00 & 0.27 & 0.27 & 0.16 & 59 & 41 & 100 & 0.11 & 41 \\
\hline 3 & 1.98 & 0.60 & 2.58 & 0.08 & 3 & 97 & 21 & 0.52 & 87 \\
\hline 4 & 6.83 & 1.03 & 7.86 & 0.64 & 8 & 92 & 5 & 0.39 & 38 \\
\hline
\end{tabular}

oxidised before release from the sediment surface (Jørgensen 1977. Nedwell et al. 1993b). Ingvorsen \& Jørgensen (1982) detected only a small proportion $(<1 \%)$ of the sedimentary sulphate reduction released from a marine sediment as sulphide. Whether or not sulphide diffuses upwards and is reoxidised, rather than being deposited within the sediment, is important to the sediment $\mathrm{N}$ budget (Blackburn \& Blackburn 1993). Lack of sulphide diffusion, and hence lack of reoxidation, leaves more $\mathrm{O}_{2}$ to nitrify upward-diffusing $\mathrm{NH}_{4}{ }^{+}$, and hence increases the $\mathrm{NO}_{3}$-generated within the sediment which will be available for subsequent denitrification. In the present case the lack of any detectable interannual changes in sedimentary sulphide concentrations argues that, on an annual basis at least, the sulphide must be re-oxidised. Re-oxidation of sulphide accounted for $31 \%$ of the annual $\mathrm{O}_{2}$ uptake at this site, leaving $16.05 \mathrm{~mol}$ of $\mathrm{O}_{2}$ for further aerobic mineralisation of organic matter. Sulphide re-oxidation could account for $83 \%$ of the sedimentary $\mathrm{O}_{2}$ uptake at Site 1 , $43 \%$ at Site 3 , but only $2 \%$ at Site 2 .

The measured net annual export of $\mathrm{NH}_{4}{ }^{+}$from Site 4 sediment was $0.64 \mathrm{~mol} \mathrm{NH}_{4}{ }^{+} \mathrm{m}^{-2} \mathrm{yr}^{-1}$. The generation of $0.24 \mathrm{~mol} \mathrm{NH}_{4}^{+} \mathrm{m}^{-2} \mathrm{yr}^{-1}$ could be driven by sulphate reduction, but the difference $\left(0.4 \mathrm{~mol} \mathrm{NH}_{4}{ }^{+} \mathrm{m}^{-2} \mathrm{yr}^{-1}\right)$ must be from additional organic matter degradation driven by $\mathrm{O}_{2}$ (Eq. 1). The formation of $0.4 \mathrm{~mol} \mathrm{NH}_{4}{ }^{+} \mathrm{m}^{-2} \mathrm{yr}^{-1}$ by aerobic mineralisation of organic matter would require a further $12.2 \mathrm{~mol} \mathrm{O}_{2}$, leaving a balance of $3.85 \mathrm{~mol} \mathrm{O}_{2}$ $\mathrm{m}^{-2} \mathrm{yr}^{-1}$. As the annual export of $\mathrm{NH}_{4}{ }^{+}$from the sediment has now been accounted for, and export of urea from the sediment was insignificant, any further $\mathrm{N}$ released from organic matter mineralisation could not be exported from the sediment as $\mathrm{NH}_{4}{ }^{+}$. The only other fate of further $\mathrm{N}$ from organic matter mineralisation could be nitrification of $\mathrm{NH}_{4}{ }^{+}$to $\mathrm{NO}_{3}{ }^{-}$, coupled to denitrification to gases, predominantly $\mathrm{N}_{2}$ (Eq. 2). The balance of $\mathrm{O}_{2}$ uptake $\left(3.85 \mathrm{~mol} \mathrm{O}_{2} \mathrm{~m}^{-2} \mathrm{yr}^{-1}\right)$ could account (Eq. 2) for a further $3.85 \mathrm{~mol}$ of sedimentary organic matter oxidised to $3.76 \mathrm{~mol} \mathrm{CO}_{2}$ and $0.06 \mathrm{~mol} \mathrm{~N}_{2}$.
Nitrate respiration would also contribute to further organic matter mineralisation, but could not generate a further flux of $\mathrm{NH}_{4}{ }^{+}$from the sediment as the annual export flux was already accounted for. Therefore we must assume that further mineralisation of organically bound $\mathrm{N}$ is to gases according to Eq. (3). The simultaneous removal of $\mathrm{NH}_{4}{ }^{+}$and $\mathrm{NO}_{3}{ }^{-}$and the concomitant production of gases has recently been demonstrated in an anaerobic denitrifying fluidized bed reactor (Mulder et al. 1995) Hence, the annual $\mathrm{NO}_{3}{ }^{-}$uptake by the sediment at Site $4\left(6.83 \mathrm{~mol} \mathrm{~m} \mathrm{~m}^{-2} \mathrm{yr}^{-1}\right)$ must have resulted stoichiometrically in the formation of a further $3.55 \mathrm{~mol}$ of $\mathrm{N}_{2}$ gas. Similar budgets could be calculated for Sites 1, 2 and 3 (Tables 2, $3 \& 4$ ). The most important conclusion is that at Sites 1,3 and $4>80 \%$ of the total $N$ flux through the sediments must have been converted to gases either by direct denitrification of $\mathrm{NO}_{3}$ transported from the overlying water, or by coupled nitrification/denitrification within the sediment, and lost from the system. At the more aerobic Site 2 only $41 \%$ of the $\mathrm{N}$ flux was denitrified.

Our conclusion about the significance of denitrification is based upon mass balance calculations of $\mathrm{N}$ which can include large unknowns. We did not measure dissolved organic nitrogen (DON) fluxes routinely and it might be considered whether this could account for the discrepancy between input and output of $N$ from the sediment. In some circumstances DON export from sediment can be high, but these tend to be either where there are active beds of benthic macrofauna (e.g. Enokson \& Samuelsson 1987, Hopkinson 1987. Boucher \& Boucher-Rodini 1988, Lomstein et al. 1989) or where there is temporary input of labile organic matter (e.g. Enoksson \& Ruden-Berg 1983, Hansen \& Blackburn 1991, Sloth et al. 1995). In the first case export of DON is predominantly as urea, which we tested for but did not detect. In the second case DON export may be due to temporarily decreased hydrolytic and mineralisation efficiency in the sediment, with the consequence that incompletely mineralised DON is 
exported. However, DON efflux subsequently drops back to negligible rates as the labile organic matter is mineralised (e.g. Enoksson \& Ruden-Berg 1983, Hansen \& Blackburn 1991). Even if there were an unknown flux of DON from the sediments of the Great Ouse as large as that of $\mathrm{NH}_{4}{ }^{+}$flux, the significance of denitrification as a calculated sink of $N$ from Site 4 , for example, would decrease only from 92 to $85 \%$ of the total $N$ flux, thus not disturbing our general conclusion about the significance of denitrification. In addition, direct measurements of denitrification in the estuaries of the Great Ouse (M. Trimmer unpubl.) and the River Colne (B. Ogilvie unpubl.) both lead to similar conclusions about the significance of sedimentary denitrification.

Nitrous oxide is an intermediate of both nitrification and denitrification (Law et al. 1992). However, it has been demonstrated (Jørgensen et al. 1984) that the vast majority of $\mathrm{N}_{2} \mathrm{O}$ produced in sediments results from denitrification. Therefore, both the high concentrations of nitrous oxide reported here (Fig. 8) and levels of supersaturation found in the sediments at Sites 1 3 and 4 can be seen to be indicative of $\mathrm{NO}_{3}{ }^{-}$respiration to $\mathrm{N}$ gases. If the above budgets were proposed assuming $\mathrm{NO}_{3}{ }^{-}$reduction to $\mathrm{NH}_{4}{ }^{+}$(Sørensen 1987), not only would we have expected to see a large net annual accumulation of $\mathrm{NH}_{4}{ }^{+}$, but would also not have expected to find such high concentrations of nitrous oxide in the sediments. Site 2 , where no significant $\mathrm{NO}_{3}{ }^{-}$fluxes were recorded, and therefore where no denitrification of intrusive $\mathrm{NO}_{3}{ }^{-}$could have occurred, was not significantly supersaturated with nitrous oxide. This further corroborated the presence of nitrous oxide as indicative of significant rates of denitrification

A number of studies have previously shown the capacity of estuarine bottom sediments to remove and denitrify $\mathrm{NO}_{3}^{-}$from the overlying water, contributing to a sometimes major attenuation of $\mathrm{N}$ fluxes through estuaries (Nedwell 1975, Billen et al. 1985, Jørgensen \& Sørensen 1988, Binnerup et al. 1992). In high $\mathrm{NO}_{3}$ environments only a small proportion of the $\mathrm{NO}_{3}{ }^{-}$is reduced to $\mathrm{NH}_{4}{ }^{+}$(Nedwell 1982, Kaspar 1983, King \& Nedweli 1987), the majority being denitrified. Moreover, the strong coupling of nitrification to denitrification also has been demonstrated in other estuarine sediments. Jenkins \& Kemp (1984) showed that $>99 \%$ of ${ }^{15} \mathrm{NH}_{4}{ }^{+}$which was oxidised to ${ }^{15} \mathrm{NO}_{3}{ }^{-}$was subsequently reduced to ${ }^{15} \mathrm{~N}_{2}$. Seitzinger et al. (1980) reported $30 \%$ loss of mineralised organic $\mathrm{N}$ via denitrification in near-shore marine sediments, although Billen (1978) recorded a smaller loss of 15 to $22 \%$ in North Sea sediments. The $\mathrm{N}$ budget reported here (Table 4) estimates that 36 to $87 \%$ of mineralised organjc $\mathrm{N}$ was lost via denitrification. The organic matter in estuarine sediments may be derived from in situ benthic primary production, by settlement from the water column of pelagic primary production and by riverine inputs of organic matter. All of these sources may contribute to sedimentary organic matter, and therefore to the overall loss of $\mathrm{N}$ within the estuary by denitrification. The estuary would therefore appear to have a large potential as a filter, to attenuate the $\mathrm{N}$ flux through the estuary not only by denitrification of $\mathrm{NO}_{3}{ }^{-}$from the water column, but also by denitrifying any $\mathrm{N}$ intercepted by biological assimilation into organic matter.

The significance of denitrification in the bottom sediments to attenuate the total flux of $\mathrm{N}$ through the estuary will depend upon the ratio between sediment surface area, water column depth, and flushing time of the estuary (Balls 1994). Multiplying the calculated annual $\mathrm{NO}_{3}$ sediment-water flux rates by the total area of sediment $\left(2.2 \mathrm{~km}^{2}\right)$ in the studied length of the Great Ouse estuary showed that the sediments would remove only $\sim 1 \%$ of the TON load $\left(10^{9} \mathrm{~mol} \mathrm{~N} \mathrm{yr}{ }^{-1}\right)$ of the Great Ouse for 1993. Such a small proportionate removal is due to the high water flow to sediment surface area ratio (TON areal load) in this section of the estuary. At the mouth of the Great Ouse below King's Lynn the estuary spreads out over an extensive area of mud flats and the ratio of water to sediment surface area (TON areal load) decreases markedly. Extrapolation of the annual $\mathrm{NO}_{3}{ }^{-}$attenuation rate measured at King's Lynn to only a modest area $\left(36 \mathrm{~km}^{2}\right)$ of these mud flats at the interface of the estuary and the Wash would account for removal of $>25 \%$ of the riverine TON load, emphasising the potential significance of these sediment-water exchanges to attenuate fluxes of nutrients through estuaries.

Acknowledgements. This work was part of the JoNuS (Joint Nutnent Study) programme funded by the Ministry of Agruculture, Fisheries and Food, the Department of the Environment and the National Rivers Authonty (all UK). The views expressed are those of the authors and do not reflect the policies of the funding departments.

\section{LITERATURE CITED}

American Public Health Association (1976) Standard methods for the examination of water and waste water. American Public Health Association, Washington, DC

Bak F, Pfennig N (1991) Microbial sulphate reduction in littoral sediment of Lake Constance. FEMS Microbiol Ecol $85: 32-42$

Balls PW (1994) Nutrient inputs to estuaries fron nine Scottish east coast nvers; influence of estuarine processes on inputs to the North Sea. Estuar Coast Mar Sci. 39:329-352

Bilien G (1978) A budget of nitrogen recycling in North Sea sediments off the Belgıan coast. Estuar Coast Mar Sci 3: $79-89$

Billen G, Somville $M$, de Becker E, Servais P (1985) A nitrogen budget of the Scheldt hydrographical basin. Neth J Sea Res 19:223-230 
Binnerup SJ, Jensen K, Revsbech NP, Jensen MH, Sørensen J (1992) Denitnfication, dissimilatory reduction of nitrate to ammonium, and nitrification in a bioturbated estuarine sediment as measured with ${ }^{15} \mathrm{~N}$ and micro sensor techniques. Appl Environ Microbiol 58:303-313

Blackburn TH, Blackburn ND (1993) Coupling of cycles and global sıgnificance of sedıment diagenesis. Mar Geol 113 $101-110$

Blackburn TH, Henriksen K (1983) Nitrogen cycling in different types of sedıments from Danısh waters. Limnol Oceanogr 28:477-493

Boucher G, Boucher-Rodoni R (1988) In situ measurements of respiratory metabolism and nitrogen fluxes at the interface of oyster beds. Mar Ecol Prog Ser 44:229-238

Boynton WR, Kemp WM, Keefe CW (1982) A comparative analysis of nutrients and other factors influencing estuarine phytoplankton production. In: Kennedy VS (ed) Estuarine comparisons. International estuarine research conference 6. Academic Press, New York, p 69-90

Brotas V, Amorim-Ferreira A, Vale C, Catarino F (1990) Oxygen profiles in intertidal sediments of Ria Formosa (S. Portugal). Hydrobiologia 207:123-129

Capone DG (1988) Benthic nitrogen fixation. In: Blackburn $\mathrm{TH}$, Sorensen J (eds) Nitrogen cycling in coastal marine environments. Scope 33, Wiley, Chichester, p 85-114

Dyer M, Grist N (1987) The ecology of the Great Ouse and Nene estuaries. In: Doody P, Barnett B (eds) The Wash and its environment. Research and survey in nature conservation 7 Nature Conservancy Council, Peterborough, UK, p $138-1.47$

Enoksson V, Ruden-Berg L (1983) A system for determining exchange between sediment and water exemplified by nitrogen flux under controlled oxygen conditions. Ecol Bull 35:243-250

Enoksson V, Samuelsson MO (1987) Nitrification and dissimilatory ammonium production and their effects on nitrogen flux over the sediment-water interface in bioturbated coastal sediments. Mar Ecol Prog Ser 36:181-189

Fichez R, Jickells TD, Edmunds HM (1992) Algal blooms in high turbidity, a result of the conflicting consequences of turbulence on nutrient cycling in a shallow water estuary Estuar Coast Shelf Sci 35:577-592

Fossing $\mathrm{H}$, Jorgensen BB (1989) Measurement of bacterial sulphate reduction in sediments: evaluation of a singlestep chromium reduction method. Biogeochemistry 8 : 205-222

Gould DJ, Dyer MF, Tester DJ (1987) Environmental quality and ecology of the Great Ouse estuary. Wat Pollut Control $86: 84-103$

Hansen LS, Blackburn TH (1991) Aerobic and anaerobic mineralization of organic material in marine sediment microcosms. Mar Ecol Prog Ser 75:283-291

Harwood JE, Kuhn AL (1970) A colorimetric method for ammonia in natural waters. Water Res 4:805-811

Hopkinson CS (1987) Nutrient regeneration in shallow-water sedıments of the estuarine plume region of the nearshore Georgia Bight, U.S.A. Mar Biol 94:127-142

Howarth RW, Giblin A (1983) Sulphate reduction in the salt marshes at Sapelo Island, Georgia. Limnol Oceanogr 28 $70-82$

Howarth RW, Swaney D, Marino R, Butler T (1995) Turbulence does not prevent nitrogen fixation by plankton in estuaries and coastal seas (reply to comment by Paerl et al.). Limnol Oceanogr 40:639-643

Howarth RW, Teal JM (1979) Sulphate reduction in a New England salt marsh. Limnol Oceanogr 24:999-1013

Ingvorsen $\mathrm{K}$, Jørgensen BB (1982) Seasonal variations in $\mathrm{H}_{2} \mathrm{~S}$ emission to the atmosphere from intertidal sediments in Denmark. Atmos Environ 16:855-865

Ingvorsen K. Jorgensen BB (1984) Kinetics of sulphate uptake by freshwater and marine spectes of Desulfovibrio. Arch Microbiol 139:61-66

Jenkins MC, Kemp WM (1984) The coupling of nutrification and denitrification in two estuarme sedments. Limnol Oceanogr 29:609-619

Jones JG, Simon BM (1980) Decomposition processes in the profundal region of Blelham Tarn and the Lund tubes J Ecol 68:493-512

Jones JC, Simon BM (1981) Differences in microbial decomposition processes in profundal and littoral lake sediments, with particular reference to the nitrogen cycle. J Gen Microbiol 123:297-312

Jergensen BB (1977) The sulfur cycle of a coastal marine sediment (Limfjorden, Denmark). Limnol Oceanogr 22: $814-832$

Jørgensen BB, Sørensen J (1985) Seasonal cycles of $\mathrm{O}_{2}, \mathrm{NO}_{3}^{-}$ and $\mathrm{SO}_{4}{ }^{2-}$ reduction in estuarine sediments: the significance of an $\mathrm{NO}_{3}{ }^{-}$reduction maximum in spring. Mar Ecol Prog Ser 24:65-74

Jargensen KS, Jensen HB, Sorensen J (1984) Nitrous oxide production from nitrification and deinitrification in marine sediment at low oxygen concentrations. Can J Microbiol 30:1073-1078

Jørgensen KS, Sørensen J (1988) Two annual maxima of nitrate reduction and denitrification in estuarine sediment (Norsminde fjord, Denmark). Mar Ecol Prog Ser 48:147-154

Kaspar HF (1983) Denitrification, nitrate reduction to ammonium, inorganic nitrogen pools in intertidal sediments Mar Biol 74:133-139

King D. Nedwell DB (1987) The adaptation of nitrate-reducing bacterial communities in estuarine sediments in response to overlying nitrate load. FEMS Microbiol Ecol 45:15-20

Law CS, Rees AP, Owens NJP (1992) Nitrous oxide: estuarine sources and atmospheric flux. Estuar Coast Shelf Sci 35: $301-314$

Lomstein BAa, Blackburn TH, Henriksen K (1989) Aspects of nitrogen and carbon cycling in the northern Bering Shelf sediment. 1. The significance of urea turnover in the mineralisation of $\mathrm{NH}_{4}{ }^{+}$. Mar Ecol Prog Ser 57:237-247

Mackereth FJH, Heron J, Talling JF (1978) Water analysis: some revised methods for limnologists. Freshwater Biologica] Association, Titus, Wilson \& Son, Kendal

Mulder A, Van de Graaf AA, Robertson LA, Kuenen JG (1995) Anaerobic ammonium oxidation discovered in a denitrifying fluidized bed reactor. FEMS Microbiol Ecol 16:177-183

Nedwell DB (1975) Inorganic nitrogen metabolism in a eutrophicated tropical mangrove estuary. Water Res 9: $221-231$

Nedwell DB (1982) Exchange of nitrate, and the end products of bacterial nitrate reduction, between seawater and sediment from a U.K. saltmarsh. Estuar Coast Shelf Sci 14: $557-566$

Nedwell DB (1987) Distribution and pool sizes of microbially available carbon in sediment measured by a microbiological assay. FEMS Microbiol Ecol 45:47-52

Nedwell DB, Blackburn TH, Wiebe WJ (1994) Dynamic turnover of organic carbon, nitrogen and sulphur in the sediments of Jamaican mangrove forest. Mar Ecol Prog Ser 110:223-231

Nedwell DB, Parkes RJ, Upton AC, Assinder DJ (1993a) Seasonal fluxes across the sediment-water interface, and processes within sediments. Phil Trans R Soc Lond 343: $519-529$ 
Nedwell DB, Takii S (1988) Bacterial sulphate reduction in sediments of a European salt marsh: acid-volatile and tinreducible products. Estuar Coast Shelf Sci 26:599-606

Nedwell DB, Walker TR, Ellis-Evans JC, Clarke A (1993b) Measurements of seasonal rates and annual budgets of organic carbon fluxes in an antartic coastal environment at Signy Island, South Orkney Islands, suggest a broad balance between production and decomposition. Appl Environ Microbiol 59:3989-3995

North Sea Task Force (1993) North Sea quality status report 1993. Oslo and Paris Commission

Parsons TR, Maita Y, Lalli CM (1984) A manual of chemical and biological methods of sea water analysis. Pergamon, Oxford

Pedersen H, Lomstein BAa, Isaksen MF, Blackburn TH (1993) Urea production by Thiosphaera pantotropha and by anaerobic enrichment cultures from marine sediments. FEMS Microbiol Ecol 13:31-36

Price NM, Harrison PJ (1987) Comparison of methods for the analysis of dissolved urea in seawater. Mar Biol 94:307-3.17

Richards FA, Cline JD, Broenkow WW, Atkinson LP (1965) Some consequences of the decomposition of organic matter in Lake Nitinat, an anoxic fjord. Limnol Oceanogr (suppl 10):R185-201

Schlegel HG (1975) Mechanisms of chemoautotrophy. In: Kinne $O$ (ed) Marine ecology. John Wiley, London, p 9-60

Second international conference on the protection of the North Sea (1987) London, 24-25 November 1987. Ministerial Declaration. Vol 8, Contribution from United Kingdom

Seitzinger S, Nixon S, Pilson MEQ, Burke S (1980) Denitrification and $\mathrm{N}_{2} \mathrm{O}$ production in near-shore marine sediments. Geochim Cosmochim Acta 44:1853-1860

This article was submitted to the editor
Skyring GW (1985) Anaerobic merobial processes in coral reef sediments. Proc 5th Int Coral Reef Cong, Tahiti 3: $421-425$

Sloth NP, Blackburn TH, Hansen LS, Risgaard-Petersen N, Lomstein BAa (1995) Nitrogen cycling in sediments with different organic loading. Mar Ecol Prog Ser 116:163-170

Sloth NP. Nielsen LP, Blackburn TH (1992) Nitrification in sediment cores measured with acetylene inhibition. Limnol Oceanogr 37:1108-1112

Sørensen J (1987) Nitrate reduction in marme sediment: pathways and interactions with iron and sulphur cycling. Geomicrobiol J 5:401-421

Tait RV (1983) Elements of marine ecology, 3rd edn. Butterworths, London

Tuttle JH, Roden EE (1993) Inorganic sulphur cycling in mid and lower Chesapeake Bay sediments. Mar Ecol Prog Ser 93:101-118

Upton AC, Nedwell DB, Parkes RJ, Harvey SM (1993) Seasonal benthic microbial activity in the southern North Sea; oxygen uptake and sulphate reduction. Mar Ecol Prog Ser 101:273-281

Watson PG, Frickers PE, Howland RJM (1993) Benthic fluxes of nutrients and some trace metals in the Tamar estuary, S.W. England. Neth J Aquat Ecol 24:135-146

Weiss RF, Price BA (1980) Nitrous oxide solubility in water and seawater. Mar Chem 8:347-359

Yoon WB, Benner R (1992) Denitrification and oxygen consumption in sediments of two south Texas estuaries. Mar Ecol Prog Ser 90:157-167

Zwolsman JJG (1994) Seasonal variability and biogeochemistry of phosphorus in the Scheldt estuary, south-west Netherlands. Estuar Coast Shelf Sci 39:227-248

Manuscript first received: March 13, 1996

Revised version accepted: July 8, 1996 